\title{
Pseudofulvimonas gallinarii gen. nov., sp. nov., a new member of the family Xanthomonadaceae
}

\author{
Correspondence \\ Peter Kämpfer \\ peter.kaempfer@umwelt.uni- \\ giessen.de
}

\section{Peter Kämpfer, ${ }^{1}$ Elena Martin, ${ }^{2}$ Nicole Lodders, ${ }^{1}$ Stefan Langer, ${ }^{3}$ Peter Schumann, ${ }^{4}$ Udo Jäckel ${ }^{2}$ and Hans-Jürgen Busse ${ }^{3}$}

\author{
${ }^{1}$ Institut für Angewandte Mikrobiologie, Justus-Liebig-Universität Giessen, D-35392 Giessen, Germany \\ ${ }^{2}$ Bundesanstalt für Arbeitschutz und Arbeitsmedizin, D-10317 Berlin, Germany \\ ${ }^{3}$ Institut für Bakteriologie, Mykologie und Hygiene, Veterinärmedizinische Universität, A-1210 Wien, \\ Austria \\ ${ }^{4}$ DSMZ - Deutsche Sammlung von Mikroorganismen und Zellkulturen, D-38124 Braunschweig, \\ Germany
}

\begin{abstract}
A Gram-stain-negative, rod-shaped, oxidase-positive, non-spore-forming bacterium $\left(\mathrm{Sa}_{15}{ }^{\top}\right)$ was isolated from the air in a duck barn. On the basis of 16S rRNA gene sequence similarity studies, the organism was grouped into the class gammaproteobacteria in the neighbourhood of the genus Fulvimonas. The quinone system consisted exclusively of ubiquinone Q-8. The polar lipid profile was mainly composed of the major lipids diphosphatidylglycerol,

phosphatidylmonomethylethanolamine and phosphatidylcholine, and moderate amounts of phosphatidylglycerol and an unidentified lipid. This profile was substantially different from that of Fulvimonas soli LMG $19981^{\top}$ examined concurrently. The polyamine pattern showed the predominant amine spermidine. Major fatty acids (iso- $\mathrm{C}_{15: 0}$, iso- $\mathrm{C}_{17: 1} \omega 9 \mathrm{c}$ and iso- $\mathrm{C}_{17: 0}$ ) were in agreement with its phylogenetic affiliation in the vicinity of Fulvimonas; however, differences in the polar lipid and fatty acid patterns and the polyamine profiles could be observed as well. On the basis of DNA-DNA pairing results, chemotaxonomic data and physiological and biochemical data, the strain can be clearly differentiated from Fulvimonas soli. It is evident that this organism represents a novel genus, for which the name Pseudofulvimonas gallinarii gen. nov., sp. nov. is proposed, with the type strain Sa15 ${ }^{\top}\left(=\mathrm{DSM} 21944^{\top}=\right.$ CCM $\left.7599^{\top}\right)$.
\end{abstract}

The genus Fulvimonas was described by Mergaert et al. (2002), with a single species, Fulvimonas soli, isolated from soil after enrichment on plasticized acetylated starch granules as a source of carbon. On the basis of $16 \mathrm{~S}$ rRNA gene sequence data, Fulvimonas soli was grouped into the neighbourhood of the genera Rhodanobacter and Frateuria. The genus was characterized by a unique fatty acid pattern, consisting almost exclusively of branched fatty acids.

Strain $\mathrm{Sa} 15^{\mathrm{T}}$ was isolated from the air sampled in a duck barn located close to Belzig, Brandenburg, Germany. Subcultivation was done on tryptone soy agar (TSA) at $28{ }^{\circ} \mathrm{C}$ for $48 \mathrm{~h}$. On this agar, the organism was able to grow at $15-45{ }^{\circ} \mathrm{C}$, but not at 10 or $50{ }^{\circ} \mathrm{C}$. Growth at $30{ }^{\circ} \mathrm{C}$ was also observed on nutrient agar and R2A, but not on MacConkey agar (all from Oxoid).

Abbreviations: DPG, diphosphatidylglycerol; PE, phosphatidylethanolamine; PG, phosphatidylglycerol; PME, phosphatidylmonomethylethanolamine; pNA, $p$-nitroanilide; pNP, $p$-nitrophenyl.

The GenBank/EMBL/DDBJ accession number for the $16 \mathrm{~S}$ rRNA gene sequence of strain Sa $15^{\top}$ is FN298515.
Gram-staining was performed as described by Gerhardt et al. (1994). Cell morphology was observed under a Zeiss light microscope at $\times 1000$, with cells grown for 3 days at $28{ }^{\circ} \mathrm{C}$ on TSA. The $16 \mathrm{~S}$ rRNA gene was analysed as described by Kämpfer et al. (2003). Phylogenetic analysis was performed using the ARB software package (Ludwig et al., 2004) and the corresponding SILVA SSURef 95 database (version July 2008; Pruesse et al., 2007) as well as the software package MEGA version 4.0 (Tamura et al., 2007) after multiple alignment of data by CLUSTAL $X$ (Thompson et al., 1997). The sequenced length of the 16S rRNA gene was 1387 bp for strain Sa15 ${ }^{\mathrm{T}}$. Nucleotide sequence distances were calculated (distance options according to the Kimura-2 model) using MEGA version 4.0.

Nucleotide sequence similarities were below $93.5 \%$ with all species of the genera Rhodanobacter, Frateuria and Dyella with validly published names. The highest similarity (93.1\%) was observed to the sequence of Fulvimonas soli (AJ311653). The phylogenetic tree shown in Fig. 1 results from a maximum-likelihood reconstruction with $50 \%$ conservatory filter (only alignment columns in which the 


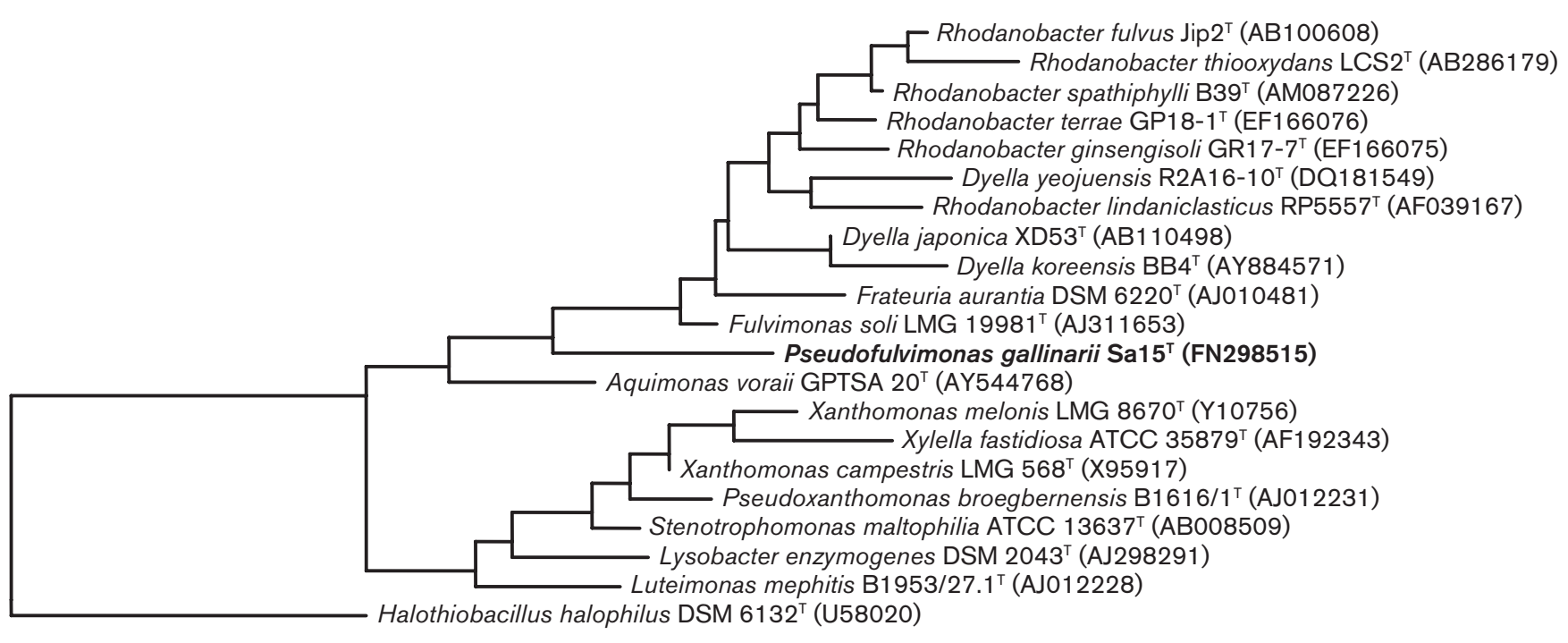

0.10

Fig. 1. Phylogenetic analysis of species most closely related to strain $\mathrm{Sa}_{15}{ }^{\top}$ based on $16 \mathrm{~S}$ rRNA gene sequences available from the European Molecular Biology Laboratory database (accession numbers are given in parentheses). The tree was constructed using the ARB software package (version December 2007; Ludwig et al., 2004) and the corresponding SILVA SSURef 95 database (version July 2008; Pruesse et al., 2007). Tree building was performed using the maximum-likelihood method with fastDNAml (Olsen et al., 1994) and $50 \%$ conservatory filter. Bar, 0.10 nucleotide substitutions per nucleotide position.

frequency of the most abundant nucleotide is equal to or above $50 \%$ are included in the calculation). Maximumlikelihood reconstructions with $30 \%$ conservatory filter and without filter resulted in identical (30\% filter) and nearly identical (without filter) trees (data not shown).

Quinones and polar lipids were extracted from biomass grown on PYE $(0.3 \%$ peptone from casein, $0.3 \%$ yeast extract, $\mathrm{pH}$ 7.2) by the integrated method and analysed as described previously (Tindall, 1990a, b; Altenburger et al., 1996). For HPLC analysis, the equipment described by Stolz et al. (2007) was employed. The quinone system of Sa $15^{\mathrm{T}}$ consisted exclusively of ubiquinone Q- 8 , which is in accordance with the quinone system detected in other members of the family Xanthomonadaceae (Finkmann et al., 2000; Busse et al., 2002; Young et al., 2007). The polar lipid profile was composed of the major lipids diphosphatidylglycerol (DPG), phosphatidylmonomethylethanolamine (PME) and phosphatidylcholine, moderate amounts of phosphatidylglycerol (PG) and an unidentified lipid (L1), and minor amounts of two unidentified aminolipids (AL1, AL2), one phospholipid (PL1) and three polar lipids (L1, L2, L3) not staining with any of the specific staining reagents (Supplementary Fig. S1, available in IJSEM Online). The unidentified aminolipid AL1 exhibited the chromatographic behaviour expected for phosphatidylethanolamine (PE), but staining with molybdenum blue for detecting phosphate groups was definitely negative. This profile was substantially different from that of Fulvimonas soli $\mathrm{LMG} 19981^{\mathrm{T}}$ examined concurrently. This was composed of the major compounds DPG and PE, moderate amounts of PG, an unidentified phospholipid (PL2) exhibiting highly hydrophobic chromatographic behaviour, an unidentified aminolipid (AL3) and an unidentified aminophospholipid (APL1), and some minor unidentified lipids (AL4, AL5, AL6, L4). In addition, a yellow pigment was detected directly after the chromatography as a very weak yellow spot, but not after staining with molybdatophosphoric acid.

Polyamines were extracted from late exponentially growing cells in PYE medium according to Busse \& Auling (1988) and analysed by HPLC using the apparatus described by Stolz et al. (2007). The polyamine pattern of strain Sa15 ${ }^{\mathrm{T}}$ contained the major compound spermidine $[11.7 \mu \mathrm{mol}(\mathrm{g}$ dry weight $\left.)^{-1}\right]$ plus spermine $\left[0.2 \mu \mathrm{mol}\left(\mathrm{g}^{\text {dry weight })^{-1}}\right]\right.$ and putrescine $\left[0.1 \mu \mathrm{mol}(\mathrm{g} \text { dry weight })^{-1}\right]$. Fulvimonas soli exhibited a similar polyamine pattern consisting of the major compound spermidine [96.3 $\mu \mathrm{mol}$ (g dry weight $)^{-1}$ ] plus putrescine $\left[2.7 \mu \mathrm{mol}(\mathrm{g} \text { dry weight })^{-1}\right]$, spermine $\left[2.0 \mu \mathrm{mol}(\mathrm{g} \text { dry weight })^{-1}\right]$ and cadaverine $[1.7 \mu \mathrm{mol}(\mathrm{g}$ dry weight $)^{-1}$. The most remarkable difference in the polyamine pattern was the huge divergence in the overall content of the major compound spermidine. However, at this time the differences should not be used as a differentiating trait until they are confirmed by analysis of additional strains of both species or closely related species. These polyamine patterns were quite similar to those 
of other members of the family Xanthomonadaceae including Xanthomonas, Pseudoxanthomonas, Thermomonas, Rhodanobacter, Frateuria, Arenimonas and Aquimonas but could be distinguished from Stenotrophomonas and Dyella (Auling et al., 1991; Hamana \& Matsuzaki, 1993; Yang et al., 1993; Busse et al., 2002; Hamana et al., 2007; Young et al., 2007).

Fatty acids were extracted and analysed as reported by Kämpfer \& Kroppenstedt (1996). The fatty acid profile of strain $\mathrm{Sa} 15^{\mathrm{T}}$ was mainly composed of iso- $\mathrm{C}_{15: 0}$, iso$\mathrm{C}_{17: 1} \omega 9 \mathrm{c}$ and iso- $\mathrm{C}_{17: 0}$. The detailed fatty acid profile is given in Table 1. Similar to Fulvimonas soli, the fatty acid pattern consisted almost exclusively of branched fatty acids. The absence of iso- $\mathrm{C}_{10: 0}$ and anteiso- $\mathrm{C}_{17: 1} \omega 9 c$, and the presence of traces of iso- $\mathrm{C}_{12: 0}$, appear to be useful for differentiation of Sa $15^{\mathrm{T}}$ from Fulvimonas soli (Table 1).

Results of the physiological characterization are given in the species description and in Table 2. Methods used have been described previously (Kämpfer et al., 1991). Strain $\mathrm{Sa} 15^{\mathrm{T}}$ and the type strain of Fulvimonas soli can be clearly differentiated on the basis of several tests.

Isolation of DNA for estimation of the $\mathrm{G}+\mathrm{C}$ content was done according to Cashion et al. (1977), and a DNA G +C content of $68.6 \%$ was estimated according to Mesbah et al. (1989). DNA-DNA hybridization experiments (two repetitions) were performed with $\mathrm{Sa} 15^{\mathrm{T}}$ and the type strain Fulvimonas soli DSM $14263^{\mathrm{T}}$ on the basis of the method described by Ziemke et al. (1998), except that, for nick translation, $2 \mu \mathrm{g}$ of DNA was labelled during a $3 \mathrm{~h}$ incubation at $15{ }^{\circ} \mathrm{C}$. Strain $\mathrm{Sa}^{\mathrm{T}} 5^{\mathrm{T}}$ showed relatively low DNA-DNA similarity to Fulvimonas soli DSM $14263^{\mathrm{T}}$ $(18 \pm 6 \%)$.

From the results of 16S rRNA gene sequencing and from the chemotaxonomic and physiological/biochemical characteristics it is evident that strain $S a 15^{\mathrm{T}}$ represents a new genus with one new species: Pseudofulvimonas gallinarii gen. nov., sp. nov.

\section{Description of Pseudofulvimonas gen. nov.}

Pseudofulvimonas (pseu.do.ful.vi.mo'nas. Gr. adj. pseudes false; N.L. fem. n. Fulvimonas generic name of a bacterium; N.L. fem. n. Pseudofulvimonas a false Fulvimonas).

Cells are non-motile, non-spore-forming rods (approx. $2 \mu \mathrm{m}$ in length). Gram-stain-negative, oxidase-positive, showing an oxidative metabolism. Polyamine patterns comprise the predominant amine spermidine. The quinone system is ubiquinone Q-8. The polar lipid profile is composed of the major lipids PME, DPG and phosphatidylcholine, and moderate amounts of PG and an unidentified lipid. The fatty acid profile contains high amounts of iso- $\mathrm{C}_{15: 0}$, iso- $\mathrm{C}_{17: 1} \omega 9 c$, iso- $\mathrm{C}_{16: 0}$ and iso$\mathrm{C}_{17: 0}$; iso- $\mathrm{C}_{10: 0}$ and anteiso $\mathrm{C}_{17: 1} \omega 9 c$ are not detected.

The DNA G + C content is $68.6 \mathrm{~mol} \%$ (for strain Sa $15^{\mathrm{T}}$ ). The type species is Pseudofulvimonas gallinarii.
Table 1. Fatty acid profiles of strain $\mathrm{Sa} 15^{\top}$ and Fulvimonas soli (percentages of fatty acids are given)

1, Sa15 ${ }^{\mathrm{T}} ; 2$, Fulvimonas soli DSM $14263^{\mathrm{T}}$ (data obtained with the same methods as in this study); 3, Fulvimonas soli (six strains, data from Mergaert et al., 2002). Summed feature 3, $\mathrm{C}_{16: 1} \omega 7 c /$ iso- $\mathrm{C}_{15: 0} 2-\mathrm{OH}$.

\begin{tabular}{|c|c|c|c|}
\hline Fatty acid & 1 & 2 & 3 \\
\hline iso- $\mathrm{C}_{10: 0}$ & & 3.9 & $<1.0$ \\
\hline iso- $\mathrm{C}_{11: 0}$ & 5.7 & 3.9 & $4.0-5.6$ \\
\hline \multicolumn{4}{|l|}{ Unknown 11.543} \\
\hline Unknown 11.799 & & 0.7 & $2.6-3.5$ \\
\hline $\mathrm{C}_{10: 0} 2-\mathrm{OH}$ & & 0.3 & \\
\hline iso- $\mathrm{C}_{11: 0} 3-\mathrm{OH}$ & 4.1 & 3.6 & $5.6-7.4$ \\
\hline iso- $\mathrm{C}_{12: 0} 3-\mathrm{OH}$ & 0.5 & 0.2 & $0.6-1.4$ \\
\hline $\mathrm{C}_{12: 0} 3-\mathrm{OH}$ & & & $<1.0$ \\
\hline iso- $\mathrm{C}_{12: 0}$ & 0.3 & & $<1.0$ \\
\hline iso- $\mathrm{C}_{13: 0}$ & & & $<1.0$ \\
\hline Unknown 13.565 & & 2.3 & $<1.0$ \\
\hline $\mathrm{C}_{14: 0}$ & 0.2 & & $<1.0$ \\
\hline iso- $\mathrm{C}_{14: 0}$ & 0.3 & 0.5 & $<1.0$ \\
\hline iso- $\mathrm{C}_{13: 0} 3-\mathrm{OH}$ & 1.9 & 1.6 & $3.8-4.3$ \\
\hline iso- $\mathrm{C}_{15: 1} \mathrm{~F}$ & 0.5 & 0.2 & $<1.0$ \\
\hline iso- $\mathrm{C}_{15: 0}$ & 28.8 & 28.2 & $25.5-31.2$ \\
\hline anteiso- $\mathrm{C}_{15: 0}$ & 0.2 & 4.7 & $2.8-4.0$ \\
\hline $\mathrm{C}_{15: 0}$ & 0.2 & & \\
\hline iso- $\mathrm{C}_{16: 0}$ & 9.0 & 8.3 & $3.7-13.2$ \\
\hline Summed feature $3^{\star}$ & 0.9 & 0.7 & $2.0-2.8$ \\
\hline $\mathrm{C}_{16: 0}$ & 2.5 & 0.8 & $0.4-2.2$ \\
\hline iso- $\mathrm{C}_{17: 1} \omega 9 c$ & 30.8 & 20.4 & $15.8-21.7$ \\
\hline anteiso- $\mathrm{C}_{17: 1} \omega 9 c$ & & 0.5 & $0.6-1.1$ \\
\hline iso- $\mathrm{C}_{17: 0}$ & 13.6 & 17.2 & $10.9-15.0$ \\
\hline anteiso- $\mathrm{C}_{17: 0}$ & 0.2 & 1.4 & $0.6-1.1$ \\
\hline $\mathrm{C}_{17: 0}$ cyclo & & 0.3 & $<1.0$ \\
\hline $\mathrm{C}_{17: 1} \omega 6 c$ & & & $0.3-1.5$ \\
\hline $\mathrm{C}_{18: 1} \omega 7 c$ & 0.2 & & \\
\hline iso- $\mathrm{C}_{18: 0}$ & & 0.3 & $<1.0$ \\
\hline
\end{tabular}

${ }^{*}$ Summed feature 3 comprises $\mathrm{C}_{16: 1} \omega 7 \mathrm{c} /$ iso- $\mathrm{C}_{15: 0} 2-\mathrm{OH}$.

\section{Description of Pseudofulvimonas gallinarii sp. nov.}

Pseudofulvimonas gallinarii (gal.li.na'ri.i. L. gen. n. gallinarium a hen house; L. gen. n. gallinarii of a hen house).

Shares all characteristics listed in the genus description. Good growth occurs on R2A agar, TSA and nutrient agar at $25-30{ }^{\circ} \mathrm{C}$. Yellow, translucent and shiny colonies with entire edges form within $24 \mathrm{~h}$, with a diameter of approximately $2 \mathrm{~mm}$. L-Alanine $p$-nitroanilide (pNA) and L-glutamate- $\gamma$-3-carboxy-pNA are hydrolysed on the basis of the method described by Kämpfer et al. (1991). The following compounds are not hydrolysed: $p$-nitrophenyl (pNP) $\beta$-D-galactopyranoside, pNP $\beta$-D-glucuronide, $\mathrm{pNP}$ $\alpha$-D-glucopyranoside, pNP $\beta$-D-glucopyranoside, pNP $\beta$-Dxylopyranoside, bis-pNP phosphate, bis-pNP phenylphosphonate, bis-pNP phosphorylcholine and L-proline pNA. The following compounds are used as sole sources of 
Table 2. Comparison of characteristics of strain $\mathrm{Sa} 15^{\top}$ and Fulvimonas soli

Both strains are positive for utilization of D-fructose and cellobiose, and hydrolysis of bis-pNP-phosphate, L-alanine-pNA and L-glutamate- $\gamma$-3-

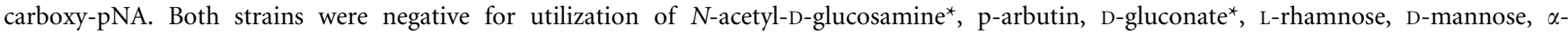
melibiose, D-ribose, sucrose, adipate ${ }^{\star}$, citrate ${ }^{\star}$, malate ${ }^{\star}$ and phenylacetate ${ }^{\star}$. APL1, aminophospholipid; PL2, unknown phospholipid.

\begin{tabular}{|c|c|c|}
\hline Characteristic & $\mathrm{Sa} 15^{\mathrm{T}}$ & Fulvimonas soli DSM $14263^{\mathrm{T}}$ \\
\hline \multicolumn{3}{|l|}{ Carbon sources utilized } \\
\hline L-arabinose $\mathrm{C}^{\star}$, D-galactose & + & - \\
\hline Glucose $^{\star}$, maltose ${ }^{\star}$, trehalose, acetate, propionate, fumarate & - & + \\
\hline \multicolumn{3}{|l|}{ Polar lipid profile } \\
\hline PME & + & - \\
\hline $\mathrm{PE}$ & - & + \\
\hline APL1 & - & + \\
\hline PL2 & - & + \\
\hline
\end{tabular}

${ }^{\star}$ Results were identical to those reported by Mergaert et al. (2002) for the type strain of Fulvimonas soli. Only those test results marked by an asterisk were compared.

carbon: L-arabinose, cellobiose, D-fructose, D-galactose, and DL-3-hydroxybutyrate (all weak). The following compounds are not used as sole sources of carbon: acetate, propionate, cis-aconitate, trans-aconitate, 4-aminobutyrate, citrate, fumarate, glutarate, itaconate, DL-lactate, malate, mesaconate, 2-oxoglutarate, pyruvate, L-alanine, $\beta$-alanine, L-aspartate, L-leucine, L-ornithine, L-proline, Lserine, $N$-acetylgalactosamine, $N$-acetyl-D-glucosamine, Larbutin, D-glucose, D-gluconate, maltose, D-mannose, $\alpha$ melibiose, L-rhamnose, D-ribose, sucrose, salicin, trehalose, D-xylose, adonitol, myo-inositol, maltitol, D-mannitol, Dsorbitol, putrescine, adipate, azelate, suberate, L-histidine, L-phenylalanine, L-serine, L-tryptophan, 3-hydroxybenzoate and phenylacetate. No acids are produced from glucose, lactose, sucrose, D-mannitol, dulcitol, salicin, adonitol, inositol, sorbitol, L-arabinose, raffinose, rhamnose, maltose, D-xylose, trehalose, cellobiose, methyl-D-glucoside, erythritol, melibiose, D-arabitol or D-mannose. In addition to the lipids listed in the genus description, minor amounts of two unidentified aminolipids, one phospholipid and two polar lipids are present.

The type strain is Sa15 $5^{\mathrm{T}}\left(=\mathrm{DSM} 21944^{\mathrm{T}}=\mathrm{CCM} 7599^{\mathrm{T}}\right)$, isolated from the air in a duck barn in Germany.

\section{References}

Altenburger, P., Kämpfer, P., Makristathis, A., Lubitz, W. \& Busse, H.J. (1996). Classification of bacteria isolated from a medieval wall painting. J Biotechnol 47, 39-52.

Auling, G., Busse, H.-J., Pilz, F., Webb, L., Kneifel, H. \& Claus, D. (1991). Rapid differentiation, by polyamine analysis, of Xanthomonas strains from phytopathogenic pseudomonads and other members of the class Proteobacteria interacting with plants. Int J Syst Bacteriol 41, 223-228.

Busse, H.-J. \& Auling, G. (1988). Polyamine pattern as a chemotaxonomic marker within the Proteobacteria. Syst Appl Microbiol 11, 1-8.
Busse, H.-J., Kämpfer, P., Moore, E. R. B., Nuutinen, J., Tsitko, I. V., Denner, E. B. M., Vauterin, L., Valens, M., Rosselló-Mora, R. \& Salkinoja-Salonen, M. S. (2002). Thermomonas haemolytica gen. nov., sp. nov., a gammaproteobacterium from kaolin slurry. Int J Syst Evol Microbiol 52, 473-483.

Cashion, P., Holder-Franklin, M. A., McCully, J. \& Franklin, M. (1977). A rapid method for the base ratio determination of bacterial DNA. Anal Biochem 81, 461-466.

Finkmann, W., Altendorf, K., Stackebrandt, E. \& Lipski, A. (2000). Characterization of $\mathrm{N}_{2} \mathrm{O}$-producing Xanthomonas-like isolates from biofilters as Stenotrophomonas nitritireducens sp. nov., Luteimonas mephitis gen. nov., sp. nov. and Pseudoxanthomonas broegbernensis gen. nov., sp. nov. Int J Syst Evol Microbiol 50, 273-282.

Gerhardt, P., Murray, R. G. E., Wood, W. A. \& Krieg, N. R. (editors) (1994). Methods for General and Molecular Bacteriology. Washington, DC: American Society for Microbiology.

Hamana, K. \& Matsuzaki, S. (1993). Polyamine distribution patterns serve as a phenotypic marker in the chemotaxonomy of the Proteobacteria. Can J Microbiol 39, 304-310.

Hamana, K., Sato, W., Gouma, K., Yu, J., Ino, Y., Umemura, Y., Mochizuki, C., Takatsuka, K., Kigure, Y. \& other authors (2007). Cellular polyamine catalogues of the five classes of the phylum Proteobacteria: distributions of homospermidine within the class Alphaproteobacteria, hydroxyputrescine within the class Betaproteobacteria, norspermidine within the class Gammaproteobacteria, and spermidine within the classes Deltaproteobacteria and Epsilonproteobacteria. Ann Gunma Health Sci 27, 1-16.

Kämpfer, P. \& Kroppenstedt, R. M. (1996). Numerical analysis of fatty acid patterns of coryneform bacteria and related taxa. Can J Microbiol 42, 989-1005.

Kämpfer, P., Steiof, M. \& Dott, W. (1991). Microbiological characterization of a fuel-oil contaminated site including numerical identification of heterotrophic water and soil bacteria. Microb Ecol 21, 227-251.

Kämpfer, P., Dreyer, U., Neef, A., Dott, W. \& Busse, H.-J. (2003). Chryseobacterium defluvii sp. nov., isolated from wastewater. Int J Syst Evol Microbiol 53, 93-97.

Ludwig, W., Strunk, O., Westram, R., Richter, L., Meier, H., Yadhukumar, Buchner, A., Lai, T., Steppi, S. \& other authors 
(2004). ARB: a software environment for sequence data. Nucleic Acids Res 32, 1363-1371.

Mergaert, J., Cnockaert, M. C. \& Swings, J. (2002). Fulvimonas soli gen. nov. sp. nov., a $\gamma$-proteobacterium isolated from soil after enrichment on acetylated starch plastic. Int J Syst Evol Microbiol 52, 1285-1289.

Mesbah, M., Premachandran, U. \& Whitman, W. B. (1989). Precise measurement of the $\mathrm{G}+\mathrm{C}$ content of deoxyribonucleic acid by highperformance liquid chromatography. Int J Syst Bacteriol 39, 159-167.

Olsen, G. J., Matsuda, H., Hagstrom, R. \& Overbeek, R. (1994). fastDNAml: a tool for construction of phylogenetic trees of DNA sequences using maximum likelihood. Comput Appl Biosci 10, 41-48.

Pruesse, E., Quast, C., Knittel, K., Fuchs, B. M., Ludwig, W., Peplies, J. \& Glöckner, F. O. (2007). SILVA: a comprehensive online resource for quality checked and aligned ribosomal RNA sequence data compatible with ARB. Nucleic Acids Res 35, 7188-7196.

Stolz, A., Busse, H.-J. \& Kämpfer, P. (2007). Pseudomonas knackmussii sp. nov. Int J Syst Evol Microbiol 57, 572-576.

Tamura, K., Dudley, J., Nei, M. \& Kumar, S. (2007). MEGA4: molecular evolutionary genetics analysis (MEGA) software version 4.0. Mol Biol Evol 24, 1596-1599.
Thompson, J. D., Gibson, T. J., Plewniak, F., Jeanmougin, F. \& Higgins, D. G. (1997). The CLUSTAL_X windows interface: flexible strategies for multiple sequence alignment aided by quality analysis tools. Nucleic Acids Res 25, 4876-4882.

Tindall, B. J. (1990a). Lipid composition of Halobacterium lacusprofundi. FEMS Microbiol Lett 66, 199-202.

Tindall, B. J. (1990b). A comparative study of the lipid composition of Halobacterium saccharovorum from various sources. Syst Appl Microbiol 13, 128-130.

Yang, P., De Vos, P., Kersters, K. \& Swings, J. (1993). Polyamine patterns as chemotaxonomic markers for the genus Xanthomonas. Int J Syst Bacteriol 43, 709-714.

Young, C.-C., Kämpfer, P., Ho, M.-J., Busse, H.-J., Huber, B. E., Arun, A. B., Shen, F.-T., Lai, W.-A. \& Rekha, P. D. (2007). Arenimonas malthae sp. nov., a gammaproteobacterium isolated from an oilcontaminated site. Int J Syst Evol Microbiol 57, 2790-2793.

Ziemke, F., Höfle, M. G., Lalucat, J. \& Rosselló-Mora, R. (1998). Reclassification of Shewanella putrefaciens Owen's genomic group II as Shewanella baltica sp. nov. Int J Syst Bacteriol 48, 179186. 